\title{
RURAL-BASED TOURISM AND LOCAL ECONOMIC DEVELOPMENT: EVIDENCE FROM INDONESIA
}

\author{
Sugeng Hadi UTOMO* \\ Faculty of Economics, Universitas Negeri Malang, Indonesia, e-mail: sugeng.hadi.fe@um.ac.id \\ Dwi WULANDARI \\ Universitas Negeri Malang, Faculty of Economics, Indonesia, e-mail: dwi.wulandari.fe@um.ac.id \\ Bagus Shandy NARMADITYA \\ Universitas Negeri Malang, Faculty of Economics, Indonesia, e-mail: bagus.shandy.fe@um.ac.id \\ Suryati ISHAK \\ Universiti Putra Malaysia, Faculty of Economics and Management, Malaysia, e-mail: suryatiis@upm.edu.my \\ Putra Hilmi PRAYITNO \\ Universiti Kebangsaan Malaysia, Faculty of Education, Malaysia, e-mail: p104853@siswa.ukm.edu.my \\ Sheerad SAHID \\ Universiti Kebangsaan Malaysia, Faculty of Education, Malaysia, e-mail: sheerad@ukm.edu.my \\ Lutfi Asnan QODRI \\ Universitas Negeri Malang, Faculty of Economics, Indonesia, e-mail: lutfiasnan@gmail.com
}

\begin{abstract}
Citation: Utomo, S.H., Wulandari, D., Narmaditya, B.S., Ishak, S., Prayitno, P.H., Sahid, S., \& Qodri, L.A. (2020). RURAL-BASED TOURISM AND LOCAL ECONOMIC DEVELOPMENT: EVIDENCE FROM INDONESIA. GeoJournal of Tourism and Geosites, 31(3), 1161-1165. $\underline{\text { https://doi.org/10.30892/gtg.31330-553 }}$
\end{abstract}

\begin{abstract}
Dealing with the environmental issue, rural-based tourism is the alternative in enhancing the welfare of the community. This study aims to examine the relationship between rural-based tourism and local economic development, and provides an insight into the development strategies ruralbased tourism. This present paper applied a quantitative approach by utilizing a rapid assessment of local economic development (RALED). Participants of this study were recruited from stakeholders, administrator and the local community in three rural-based tourism in Batu of East Java, Indonesia. The findings indicate that the six dimensions have met the good and excellent category. However, the attention needs to be given to the three least dimensions, including target group, management process and policy focus and synergy. These results suggest that rural-based tourism is strongly linked with the local community due to the community involvement for tourism development.
\end{abstract}

Key words: local economic development, rural-based tourism, community welfare, tourism sectors

\section{INTRODUCTION}

Tourism sector becomes a central issue and plays a pivotal role in the Indonesian economy. The underlying reason is that the tourism sector allows more significant job opportunities for the circumstances, both direct and indirectly (Bunghez, 2016). The direct advantage of tourism can be seen by increasing local and regional revenue from tax and retribution. Meanwhile, the indirect effect can be felt by opportunities in opening a small business (Kader, 2017; Bernini and Cracolici, 2016). Besides, some scholars believe that tourism sectors promote community well-being (Naidoo and Sharpley, 2016; Pyke et al., 2016; Hughes and Scheyvens, 2018).

Considering the significant role of the tourism sector in various dimensions, the development of tourism needs to be enlarged by both government and private. Among the existing tourism sector, rural-based tourism involves synergy between community, culture and tourism (Lulcheva and Arseniou, 2018). The development of the rural-based model is arguable for many reasons. First, Indonesia has fascinating geographical features, infrastructures, natural potential, and demand for natural tourism. Second, it helps to alleviate poverty and reduce the community well-being between rural and urban society. Besides, rural-based tourism offers rural authenticity, such as socioeconomic life, socio-culture, customs, and daily life. Recent literature has documented that community is the primary subject on the development of ruralbased tourism and tourism sustainability (Seyfi et al., 2019; Mak et al., 2017; Harwood, 2010). However, among previous studies, there is little attention to analysing the concept of community or how community affects the achievement. For instance, Scherl and Edw ards (2007) demonstrated that the local community is the people with an identic identity which probably involved in various aspects of work. Also, Zhuang et al. (2019) noted that local community often has customary rights relating to the territory and its natural resources and strongly linked with the region culturally, socially, economically and spiritually.

In the development of a tourism destination, there should be several conditions that must be met, among others, namely good accessibility, there are interesting objects, the public and officials accept or support, security, climate tourism facilities available, associated with other purposes that are known to the community (Hadiwijoyo, 2012; Rohmadin, 2016; Arida and Pujani, 2017). Village tourism consists of various forms such as agricultural / livestock tourism, cultural tourism, nature tourism, adventure tourism, and eco-tourism.

The development of rural-based tourism has attracted and gained interest among scholars in the numerous countries such as in Romania (Bunghez, 2016), China (Guo and Sun, 2016; Gao and Wu, 2017), India (Srivastava, 2016; Sati, 2019). In the context of Indonesia, particularly in East Java, the government and policy makers have also concerned in developing a rural-based tourism (Vega et al., 2018; Utomo

\footnotetext{
* Corresponding author
} 
and Satriawan, 2017; Purwanti, 2019; Khoirunnisa and Kholil, 2019). Utomo and Satriawan (2017) researched the development of village-based tourism in Karang ploso in Malang regency, while Vega et al. (2018) focused on the community participation in enhancing rural-based tourism in Tulung rejo, Batu. In addition, Purwanti (2019) concerned on the strategies to provide a development of village-based tourism.

The purposes of this present study are aimed in two folds. First, it examines the relationship between rural tourism and local community welfare comprehensively. Despite the increasing interest in village-based tourism (e.g., Gartner, 2004; Danglah, 2010; Nair et al., 2015), however, scholars pay little attention to whether rural-based tourism impacts the community well-being. The focus of the present study is conducted in Batu of East Java unique due to the more exceptional growth of tourism sector and village-based tourism compared to numerous regions in Indonesia. Second, the existing works of literature focus on the qualitative method which cover narrow respondents (e.g., Attar et al., 2013; Sari, 2014), while this study attempts to evaluate current development of rural-based tourism by using hexagon rapid assessment of local economic development which also potentially promotes and strengthens the weak and highest dimensions.

\section{MATERIALS AND METHODS}

The study applied a quantitative approach to mapping out local economic development factors that combine rapid assessment of Local Economic Development (LED) status and prioritized weighting of LED aspects. The participants of this study were gathered from stakeholders, administrator and the local community in three rural-based tourism in Batu of East Java, Indonesia. The underlying reason is that Batu has shown the most growing tourism sectors in East Java, particularly village-based tourism. The data were collected using questionnaires and in-depth interviews with respondents. Furthermore, the data were estimated using the Rapid Assessment of Local Economic Development (RALED), which is a modification from RAPfish (Rapid Appraisal of Fisheries). RALED with Hexagonal local economic development which is intended to quickly identify the lever factor of each component of Hexagonal local economic development. Rapid Assessment of Local Economic Development indicator covers the local economic development by the regional agency planning of East Java and Batu. The local economic development is predicted by six aspects, including target group, locational factor, policy focus and synergy, sustainability, process management, and governance (Table 1). For estimating the performance of each variable leverage, it undergoes natural typology consisting of four categories. First, if the index value $<25$, means that the aspect is in the poor category. If the index value ranging between $25-50$ meaning the aspect is in average condition. In addition, If the index value is ranging between $51-75$, means that the aspect is in a good category. Lastly, if the index value $>75$ means that the aspect is in the excellent category.

Table 1. The indicators of each dimension

\begin{tabular}{|c|c|c|c|c|c|}
\hline \multicolumn{7}{|c|}{ Dimensions } \\
\hline Target group & Location & Policy focus and synergy & Sustaina-bility & Process management & Governance \\
\hline Permit for investment & Public facilities & Regional policy & Natural conservation & Planning evaluation & Association member \\
\hline Government incentives & Environmental quality & Community policy & Waste management & Problem solving & Government policies \\
\hline Entrepreneur-ship training & Skilled worker & Centre of growth & Environmental impact & Monitoring and evaluation & Public Administration \\
\hline $\begin{array}{c}\text { Management and } \\
\text { technology }\end{array}$ & $\begin{array}{c}\text { Clean water } \\
\text { availability }\end{array}$ & Poverty alleviation & $\begin{array}{c}\text { Local community } \\
\text { welfare }\end{array}$ & Administration involvement \\
\hline Government Facilities & Communication easiness & Skill enhancement & Business partner & Tourism development & Business Partnership \\
\hline Business marketing & Transportation & Regional promotion & Sustainability facilities & Regional assessment & Marketing partnership \\
\hline Business prospectus & Location easiness & investment & & Mapping economic potential & Infrastructure sector \\
\hline
\end{tabular}

\section{RESULTS DISCUSSIONS}

\section{Sensitivity of Local Economic Development}

The results of the analysis using a rapid assessment of local economic development (RALED) are provided in the following figures. First, the leverage score for the target group is presented in Figure 1. In general, the score of the target group dimension is ranging from 2.764 to 9.637. The most sensitive index is facilities for business, while the lowest score is entrepreneurship and training.

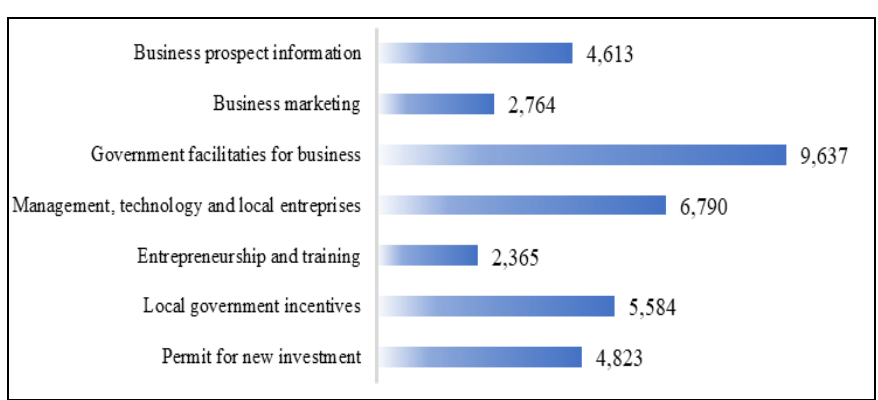

Figure 1. Leverage score for target group

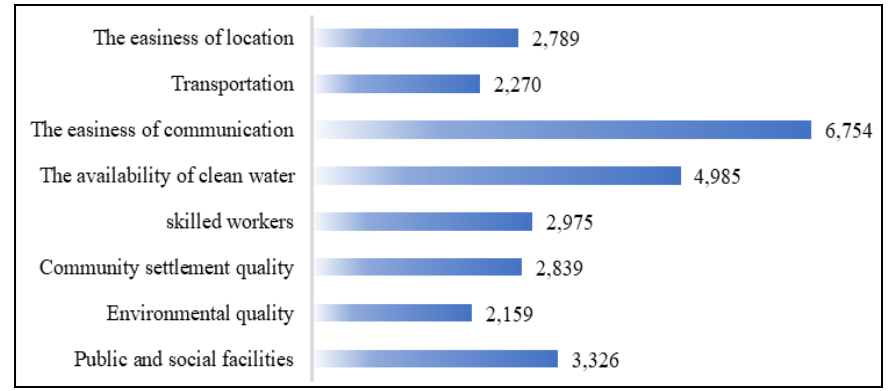

Figure 2. Leverage score for location

The findings of the study show that the government has provided entrepreneurship program and training for the local community. The underlying rationale is that entrepreneurship program can promote a community being entrepreneurs and potentially increase the economic welfare (Saptono et al., 2019; Aquino et al., 2018). Also, the government has conducted appropriate business marketing which is shown by the number of visitors, particularly in the weekend and high season. Based on the figure, it can be pointed out that government facilities, management, technology and local enterprises and local government incentives are the most critical variables in supporting rural-based tourism and local economic development. The enhancement of rural-based tourism by the community and surrounding society tend to use the conventional method. They are more likely to keep the natural conservation instead of rapidly increase their business. However, the role of technology is very crucial for the tourism sector (Navío-Marco et al., 2018). On the other hand, the government failed in facilitating community in providing their ideas to enlarge the business. In fact, the development of rural-based tourism is initiated by the local community to enhance their welfare. This finding is strongly associated with social capital in the community, which lead to provide resources like network, funding, entrepreneurship (Putnam, 2000).

Figure 2 depicts the information about leverage score for location. Based on the figure, it can be noted that the three most sensitive items are easiness of communication, the availability of clean water and public and social facilities. The ease of communication is the main 
problem in the area surrounding the mountains. It has a lack of signal of telecommunication providers. Despite the fact that it has a great location, however, it faced the lack of water availability. In this case, the lack of clean water means the inadequate of rural-based tourism in providing clean water in the area. Some of rural-based tourism have not appropriately provided lavatories with the national standard. Furthermore, the public facilities such as mosque, parks and roads have provided in the midtown; however, it is not developed yet in the rural areas in Batu of East Java. The needs for the development of the three main variables are considerable. This findings confirms the previous studies which showed a positive relationship between public facilities and rural-tourism development (Aziz et al., 2018), communication easiness and rural-based tourism (Bambi et al., 2019), and clean water in supporting tourism sector (Pan et al., 2018).

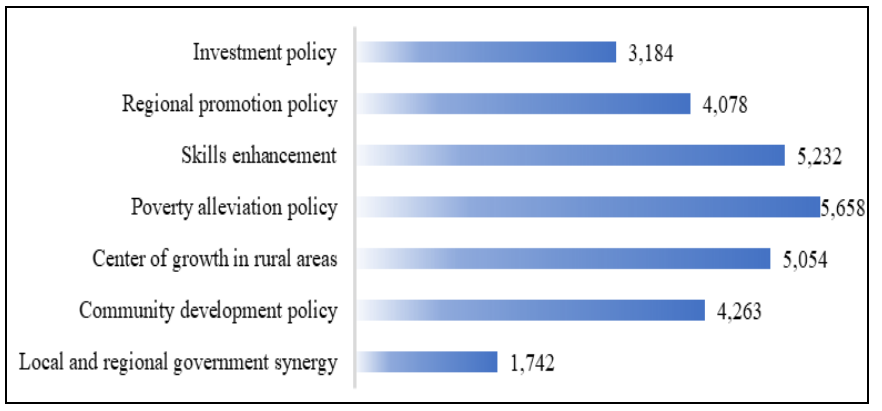

Figure 3. Leverage score for policy focus and synergy

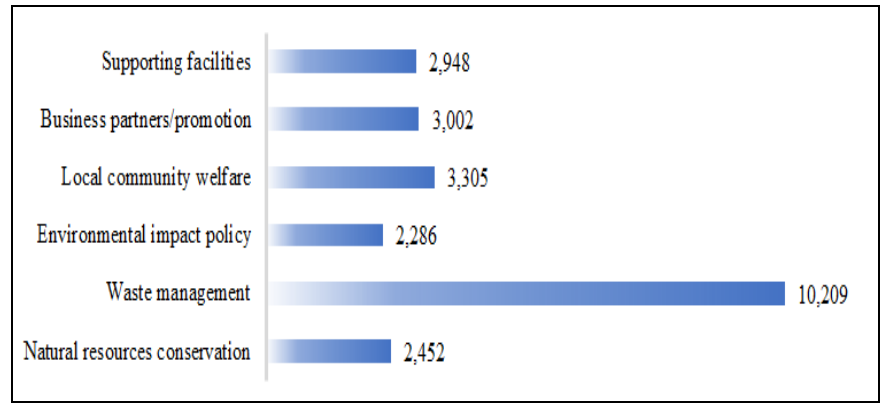

Figure 4. Leverage score for sustainability

Figure 3 informs the leverage score for policy focus and synergy. From the figure, it can be known that the most sensitive index is poverty alleviation, while the lowest index is local and regional synergy. Also, the second and third sensitives are centre for rural areas and skill enhancement. These findings imply that the three most sensitive items need to be addressed if they would like to boost the rural-based tourism and local economic development. A prior study by Xu et al. (2018) mentioned a poverty reduction through tourism development. Based on this finding, it is suggested to provide a policy which focuses on the impact of rural-based tourism and poverty alleviation. In addition, the centre of growth needs to be considered by business actor, local community, and local government and also involve the university which plays a role as researchers and advisors. Skill-workers are the central issue in the engagement of resident. In fact, the local community takes part as the low-middle workers in the establishment of tourism. Therefore, pieces of training on skills and language helps individuals to develop their capabilities. Nevertheless, the synergy between local and regional have an adequate collaboration. It can be further capital to promote local community through rural-tourism development.

Figure 4 presents the result of RALED test from the sustainability perspectives. The sustainability is proxied by six indicators, namely supporting facilities, business partner, local community welfare, environmental impact, waste management and nature conservation. From the figure, the highest consideration is waste management, while the lowest one is the environmental impact. In the development of ruralbased tourism in several places in Batu rules out waste management. They focus on providing various photo spots instead of equipping with waste management. Actually, in several areas have provided waste management, well-known as a waste bank which plays intermediaries role like a general bank which manages money. Wulandari et al. (2017) pointed out that waste bank can improve the local community welfare. The waste banks have been localized by the community in the housing complex but not implemented yet in rural-based tourism. Therefore, it will be the main concern for further development. Besides, business partnership and promotion need to be considered due to the critical role to enhance the tourism site. This finding is in accordance with Pradipta (2017); Hashimoto and Telfer (2010), who remarked a need for partnership across rural-tourism development. In fact, the current condition, the funding is the crucial issue that makes the development of the tourism area inappropriate.

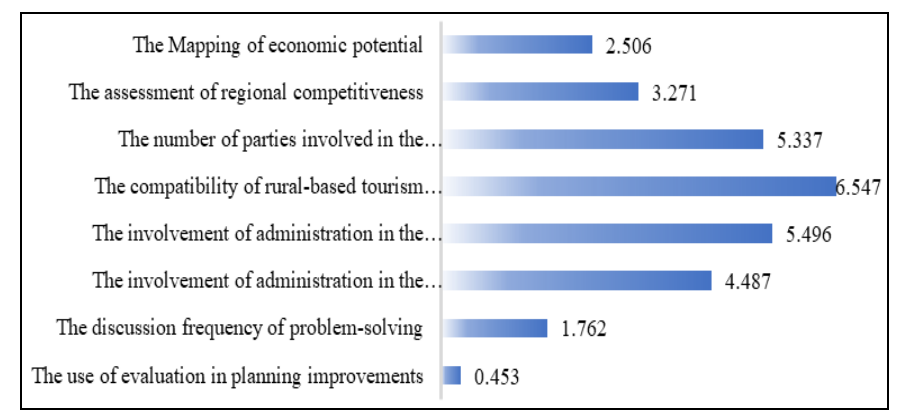

Figure 5. Leverage score for management process

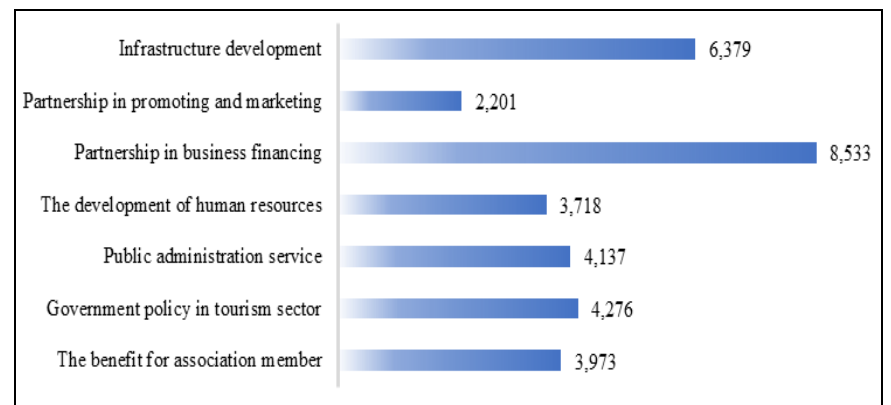

Figure 6. Leverage score for governance

Figure 5 illustrates the leverage score for the management process. From the figure, the government has successfully evaluated within planning improvement. However, other evaluations need to be elaborated. For instance, the compatibility of rural-based tourism development. Some of administrators and owners think solely on the financial benefits instead of considering the suitable with culture, location, and the local community. Thus, this makes a problem in tourism itself in its development. Second, the number of parties involved in the development of the local community is restricted to certain people. For this reason, the involvement of various parties is needed to enhance local economic development. This result is in agreement with prior studies by Panyik et al. (2011); Pongponrat (2011), which pointed that the success and failure of tourism development is closely linked with the management process.

Figure 6 provides the leverage index for governance. From the figure, it is known that a partnership in business financing is the primary issue. Graci (2013) confirmed that collaboration through multi-stakeholder partnerships had been seen as an effective way to support initiatives in tourism development in Indonesia. Also, infrastructure development in some areas in rural-based tourism suffers inappropriate in showing a brand image for rural-based tourism. Theoretically, the existence of rural-based tourism should consider the underlying aspects such as infrastructure. The third is the government support in tourism policy. In fact, the local government is more concerned about largescale tourism instead of rural-tourism, which is relatively small. For these matters, those variables need to be attracted to enhance rural- 
tourism development and local community development. This finding confirms a previous work by Amore and Hall (2016), who mentioned the role of governance in encouraging the processes and community responses the rural-tourism development.

\section{The Status and Strategies for Rural-Based Tourism Development}

The existence of local economic development (LED) can be one of the strategies being undertaken to improve the economy of the community in Batu of East Java. The determination of LED status is aimed to provide the general existing condition of LED in the region. From the six aspects of kite diagram, it can be illustrated that the point which further away from point 0 is the best value in the element of sustainable development. In other words, it is successful, and it achieves high scores compared to other aspects. The detail of the results of the study is provided in Figure 7.

Figure 7 provides information on the local economic development status, which proxied by six indicators, namely target group, locational factor, policy focus and synergy, sustainability, process management, and governance. From the figure, it can be seen that sustainability reaches the highest point, while the target group posits the lowest score. It implies that the local community and the existing of rural-based tourism has considered such factors as nature conservation, environmental impact and sustainability facilities. Also, most of the tourism site and community are having waste management, namely, waste bank. The existence of waste bank does not only enhance the sustainability factor, but it also increases the local economic welfare (Wulandari et al., 2017).

Furthermore, two indicators, namely government and locational factor, have a slightly different score which is 82.49 and 83.68 , respectively. In acquaintance with locational dimension, the rural-based tourism areas are facilitated with appropriate infrastructures which allow big vehicles to reach for the general tourism site in mid-town rather than rural-based tourism. In addition, the local government has provided such public facilities, including hospitals, public parks, and hotels.

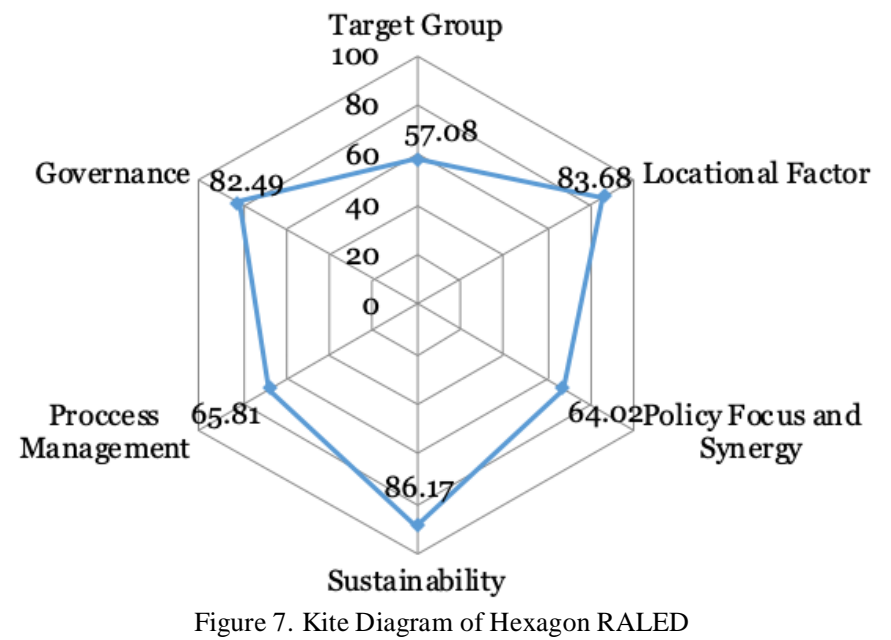

Despite the fact that all dimension are in good and excellent categories, the least aspects, including, target group, policy focus and synergy and process management, need to be enhanced. The target group covers several components which are permitted to investment, the government incentives, entrepreneurship training, management and technology, government facilities and marketing. Meanwhile, the process of management aspect shelters planning evaluation, regional assessment and development and mapping economic potential that needs to be concerned. The tourism potential of hexagonal analysis by engaging RALED. The aspect of target groups needs to be explored due to the lowest index. Therefore, it requires the appropriate strategy to enhance the dimension. First, it needs synergy between local and regional government to monitor and evaluate the existing planning that has been running. This is due to the fact that there are many tourism sites in Batu Malang, which involve the participation of the local community. Next, it needs to provide insights for the local community to understand the priority of planning; thus, they can that the standpoint to develop the potential business to support the existing tourism sector. Lastly, local authorities and communities are important to promote tourism or providing information on through technological developments without having to rely on the local website.

\section{CONCLUSION}

This study attempts to investigate the correlation between rural-based tourism and local economic development. Utilizing rapid assessment of local economic development (RALED), The findings showed that the six dimensions had met the good and excellent category. However, the attention needs to be given to the three least dimensions, including target group, management process and policy focus and synergy. These results suggest that rural-based tourism is strongly linked with the local community due to the community involvement for tourism development. For further studies, it is recommended to elaborate on the model for local economic development by synergizing policymakers, universities, communities, and entrepreneurs.

\section{Acknowlegments}

This study was funded by the Universitas Negeri Malang Research Grant (4.3.633/UN32/KP/2020). We also thank representatives of the rural who have helped and assisted during the research.

\section{REFERENCES}

Amore, A., \& Hall, C.M. (2016). From governance to meta-governance in tourism? Re-incorporating politics, interests and values in the analysis of tourism governance. Tourism recreation research, 41(2), 109-122. https://doi.org/10.1080/02508281.2016.1151162

Arida, I.N.S., \& Pujani, L.K. (2017). Kajian Penyusunan Kriteria-Kriteria Desa Wisata Sebagai Instrumen Dasar Pengembangan Desawisata. Jurnal Analisis Pariwisata, 17(1), 1-9.

Attar, M., Hakim, L., \& Yanuwiadi, B. (2013). Analysis of the potential and direction of policy development strategies for ecotourism villages in the District of Bumiaji - Kota Batu (Indonesian Origin). Journal of Indonesian Tourism and Development Studies, 1(2), 68-78. 
Aquino, R.S., Lück, M., \& Schänzel, H.A. (2018). A conceptual framework of tourism social entrepreneurship for sustainable community development. Journal of Hospitality and Tourism Management, 37, 23-32. https://doi.org/10.1016/j.jhtm.2018.09.001

Aziz, R.C., Hashim, N.A.A.N., \& Awang, Z. (2018). Tourism development in rural areas: Potentials of appreciative inquiry approach. Journal of Tourism, Hospitality \& Culinary Arts, 10(1), 59-75.

Bambi, G., Iacobelli, S., Rossi, G., Pellegrini, P., \& Barbari, M. (2019). Rural tourism to promote territories along the ancient roads of communication: case study of the rediscovery of the St. Francis's Ways Between Florence and La Verna. European Countryside, 11(3), 462-474. https://doi.org/ 10.2478/euco-2019-0025

Bernini, C., \& Cracolici, M.F. (2016). Is participation in the tourism market an opportunity for everyone? Some evidence from Italy. Tourism economics, 22(1), 57-79. https://doi.org/10.5367/te.2014.0409

Bunghez, C.L. (2016). The importance of tourism to a destination's economy. Journal of Eastern Europe Research in Business and Economics, 1-9. https://doi.org/10.5171/2016.143495

Danglah, D.G. (2010). Developing rural based tourism as a strategy for rural development in Nigeria. International Journal of Creativity and Technical Development, 2, 1-3.

Gao, J., \& Wu, B. (2017). Revitalizing traditional villages through rural tourism: A case study of Yuanjia Village, Shaanxi Province, China. Tourism Management, 63, 223-233. https://doi.org/10.1016/j.tourman.2017.04.003

Gartner, W.C. (2004). Rural tourism development in the USA. International Journal of Tourism Research, 6(3), 151-164. https://doi.org/10.1002/jtr.481

Graci, S. (2013). Collaboration and partnership development for sustainable tourism. Tourism Geographies, 15(1), 25-42. https://doi.org/10.1080/14616688.2012.675513

Guo, Z., \& Sun, L. (2016). The planning, development and management of tourism: The case of Dangjia, an ancient village in China. Tourism Management, 56, 52-62. https://doi.org/10.1016/j.tourman.2016.03.017

Hadiwijoyo, S.S. (2012). Perencanaan pariwisata perdesaan berbasis masyarakat (sebuah pendekatan konsep). Graha Ilmu Publisher, Yogyakarta - Indonesia.

Harwood, S.K. (2010). Planning for community based tourism in remote areas: bird watching in Arfak Mountains West Papua. Charles Darwin University.

Hashimoto, A., \& Telfer, D.J. (2010). Developing sustainable partnerships in rural tourism: The case of Oita, Japan. Journal of Policy Research in Tourism, Leisure and Events, 2(2), 165-183. https://doi.org/10.1080/19407963.2010.482276

Hughes, E., \& Scheyvens, R. (2018). Development alternatives in the Pacific: How tourism corporates can work more effectively with local communities. Tourism Planning \& Development, 15(5), 516-534. https://doi.org/10.1080/21568316.2018.1478881

Kader, A. (2017). Development planning of tourism destination as local superior economy sector: study at Tidore city islands. International Journal of Management and Administrative Sciences (IJMAS), 5(03), 19-25. www.ijmas.org

Khoirunnisa, N., \& Kholil, A.Y. (2019). Marketing mix strategy of temas ecological tourism village in batu city (Indonesian Origin). Buana Sains, 18(2), 161-170.

Leonandri, D., \& Rosmadi, M.L.N. (2018). The role of tourism village to increase local community income. Budapest International Research and Critics Institute (BIRCI-Journal): Humanities, 1(4), 188-193. https://doi.org/10.33258/birci.v1i4.113

Lulcheva, I., \& Arseniou, S. (2018). Synergy-Rural tourism and sustainable development of rural areas in Bulgaria. Scientific Papers Series Management, Economic Engineering in Agriculture and Rural Development, 18(3), 243-250.

Mak, B.K., Cheung, L.T., \& Hui, D.L. (2017). Community participation in the decision-making process for sustainable tourism development in rural areas of Hong Kong, China. Sustainability, 9(10), 1695. https://doi.org/10.3390/su9101695

Naidoo, P., \& Sharpley, R. (2016). Local perceptions of the relative contributions of enclave tourism and agritourism to community well-being: The case of Mauritius. Journal of Destination Marketing \& Management, 5(1), 16-25. https://doi.org/10.1016/j.jdmm.2015.11.002

Nair, V., Munikrishnan, U.T., Rajaratnam, S.D., \& King, N. (2015). Redefining rural tourism in Malaysia: A conceptual perspective. Asia Pacific Journal of Tourism Research, 20(3), 314-337. https://doi.org/10.1080/10941665.2014.889026

Navío-Marco, J., Ruiz-Gómez, L.M., \& Sevilla-Sevilla, C. (2018). Progress in information technology and tourism management: 30 years on and 20 years after the internet-Revisiting Buhalis \& Law's landmark study about eTourism. Tourism Management, 69, 460-470. https://doi.org/10.1016/j.tourman.2018.06.002

Pan, S.Y., Gao, M., Kim, H., Shah, K.J., Pei, S.L., \& Chiang, P.C. (2018). Advances and challenges in sustainable tourism toward a green economy. Science of the Total Environment, 635, 452-469. https://doi.org/10.1016/j.scitotenv.2018.04.134

Panyik, E., Costa, C., \& Rátz, T. (2011). Implementing integrated rural tourism: An event-based approach. Tourism Management, 32(6), 1352-1363. https://doi.org/10.1016/j.tourman.2011.01.009

Pongponrat, K. (2011). Participatory management process in local tourism development: A case study on fisherman village on Samui Island, Thailand. Asia Pacific Journal of Tourism Research, 16(1), 57-73. https://doi.org/10.1080/10941665.2011.539391

Purwanti, I. (2019). Strategi kelompok sadar wisata dalam penguatan desa wisata. JISIP: Jurnal Ilmu Sosial Dan Ilmu Politik, 8(3), $101-107$.

Pyke, S., Hartwell, H., Blake, A., \& Hemingway, A. (2016). Exploring well-being as a tourism product resource. Tourism Management, 55, 94-105. https://doi.org/10.1016/j.tourman.2016.02.004

Putnam, R. (2000). Bowling alone: The collapse and renewal of American community. New York: Simon \& Schuster.

Rohmadin, S. (2016). Strategi pengembangan kawasan wisata berbasis pembangunan berkelanjutan di Kabupaten Ende Provinsi Nusa Tenggara Timur. Jurnal Politik Pemerintahan, 9(1), 141-153.

Saptono., Wibowo, A., Narmaditya, B.S., Kusumojanto, D.D., \& Hermawati, M. (2019). Determinant factors of development entrepreneurial education: lesson from senior high school in indonesia. Universal Journal of Educational Research, 7(12), 2837-2843.

Sari, A.M. (2014). The application of the concept of green economy in the development of tourism villages as an effort to realize development with environmental insights (IndoF\&nesian Origin). Jurnal Administrasi Publik, 2(4), 765-770.

Sati, V.P. (2019). Potential and forms of sustainable village tourism in Mizoram, Northeast India. Journal of Multidisciplinary Academic Tourism, 4(1), 49-62. http://dx.doi.org/10.31822/jomat.527278

Scherl, L.M., \& Edwards, S. (2007). Tourism, indigenous and local communities and protected areas in developing nations. Tourism and protected areas: Benefits beyond boundaries, 71-88.

Seyfi, S., Michael Hall, C., \& Fagnoni, E. (2019). Managing world heritage site stakeholders: A grounded theory paradigm model approach. Journal of Heritage Tourism, 14(4), 308-324. https://doi.org/10.1080/1743873X.2018.1527340

Srivastava, S. (2016). Agritourism as a Strategy for the Development of Rural Areas Case Study of Dungrajya Village, Southeast Rajasthan, India. Journal of Medical and Dental Science Research, 3(6), 35-39.

Utomo, S.J., \& Satriawan, B. (2017). Strategi pengembangan desa wisata di Kecamatan Karangploso Kabupaten Malang. Neo-Bis, 11(2), 142-153.

Vega, A.N., Kusumawati, A., \& Hakim, L. (2018). Partisipasi masyarakat dalam pengembangan desa wisata serta dampaknya terhadap perekonomian warga di Desa Tulungrejo Kota Batu. Jurnal Administrasi Bisnis, 61(3), 48-56.

Wulandari, D., Utomo, S.H., \& Narmaditya, B.S. (2017). Waste bank: waste management model in improving local economy. International Journal of Energy Economics and Policy, 7(3), 36-41

Xu, H., Wang, C., Wu, J., Liang, Y., Jiao, Y., \& Nazneen, S. (2018). Human poverty alleviation through rural women's tourism entrepreneurship. Journal of China Tourism Research, 14(4), 445-460. https://doi.org/10.1080/19388160.2018.1507860

Zhuang, X., Yao, Y., \& Li, J J. (2019). Sociocultural impacts of tourism on residents of world cultural heritage sites in China. Sustainability, 11(3), 840. https://doi.org/10.3390/su11030840 